2. To: (Receiving Organization)

Characterization Engineering

\section{Proj./Prog./Dept./Div.:}

Characterization

8. Originator Remarks:

This document is the Design Review Report for modifications to the Foot Clamp. It is being routed for review and approval.

\section{Receiver Remarks:}

3. From: (Originating Organization)
Equipment Engineering
$\begin{aligned} & \text { 6. Design Authority/Design Agent/Cog. Engr.: } \\ & \text { G. P. Janicek }\end{aligned}$

3. From: (Originating Organization)

G. P. Janicek

4. Related EDT No.:

N/A

7. Purchase Order No.:

$\mathrm{N} / \mathrm{A}$

9. Equip./Component No.:

$\mathrm{N} / \mathrm{A}$

10. System/Bldg./Facility:

$\mathrm{N} / \mathrm{A}$

12. Major Assm. Dwg. No.:

$\mathrm{N} / \mathrm{A}$

13. Permit/Permit Application No.:

N $/ A$

14. Required Response Date:

\begin{tabular}{|c|c|c|c|c|c|c|c|c|}
\hline 15. & & DATA TRA & NSMITTE & & (F) & (G) & (H) & (l) \\
\hline $\begin{array}{l}\text { (A) } \\
\text { Ifem } \\
\text { No. }\end{array}$ & (B) Document/Drawing No. & $\begin{array}{l}\text { (C) Sheet } \\
\text { No. }\end{array}$ & (D) Rev. & (E) Title or Description of Data Transmitted & $\begin{array}{l}\text { Agproval } \\
\text { Desig- } \\
\text { nator }\end{array}$ & $\begin{array}{l}\text { Reason } \\
\text { for Trans- } \\
\text { mittal }\end{array}$ & $\begin{array}{c}\text { Origi- } \\
\text { nator } \\
\text { Dispo- } \\
\text { stion }\end{array}$ & $\begin{array}{c}\text { Recoiv- } \\
\text { er } \\
\text { Dispo- } \\
\text { sition }\end{array}$ \\
\hline 1 & $R P P-5628$ & & 0 & Formal Design Review-Foot & SQ & 1 & 1 & 1 \\
\hline & & & & Clamp Modification & & & & \\
\hline & & & & & & & & \\
\hline & & & & & & & & \\
\hline & & & & & & & & \\
\hline & & & & & & & & \\
\hline & & & & & & & & \\
\hline
\end{tabular}

16.

KEY

\begin{tabular}{|c|l|}
\hline Approval Designator (F) & \\
\hline E, S, Q, D OR N/A & 1. Approval \\
(See WHC-CM-3-5, & 2. Release \\
Sec. 12.7) & 3. Information \\
\hline
\end{tabular}

17.

Reason for Transmittal (G)

Disposition $(\mathrm{H})$ \& (I)

4. Review
5. Post-Review
6. Dist. (Receipt Acknow. Required)

1. Approved

2. Approved w/comment

3. Disapproved w/comment
4. Reviewed no/comment

5. Reviewed w/comment 6. Receipt acknowledged SIGNATURE/DISTRIBUTION (See Approval Designator for required signatures)

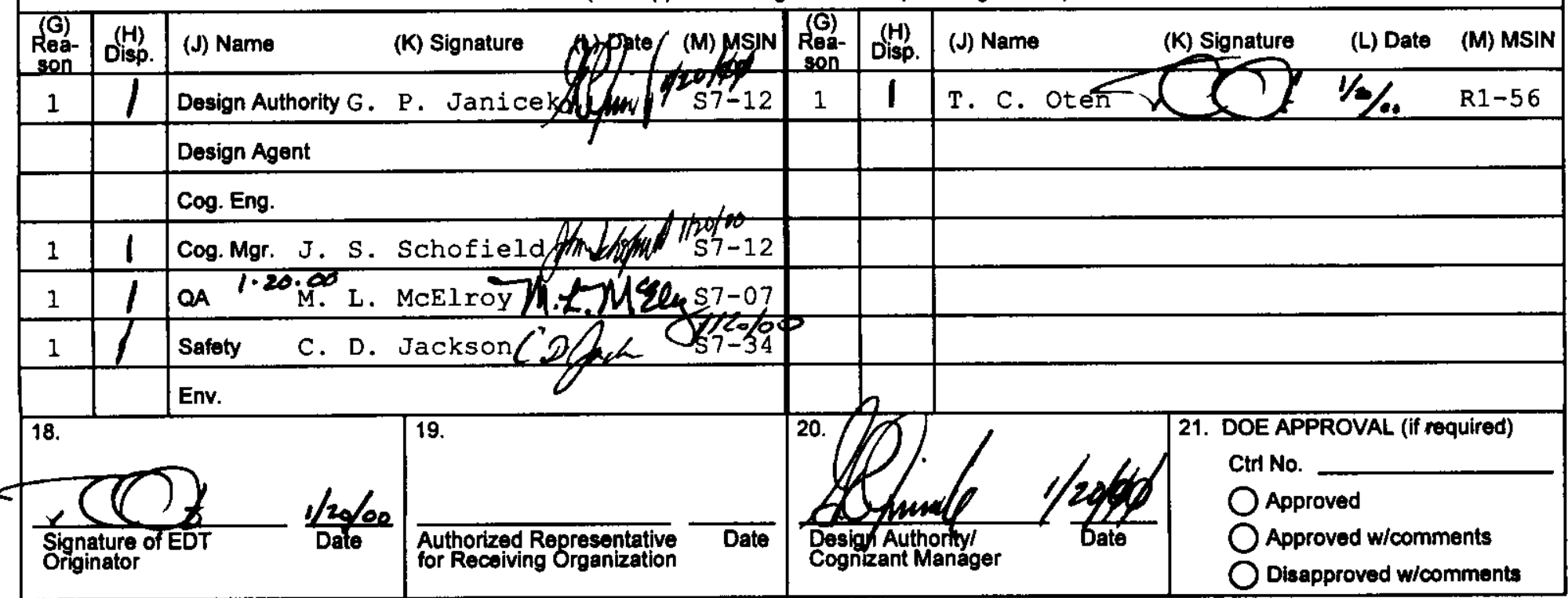




\title{
Formal Design Review Foot Clamp Modification
}

\author{
Tinothy C. Oton \\ CH2M Hill, Hanford Group, Inc. \\ Richland, WA 99352

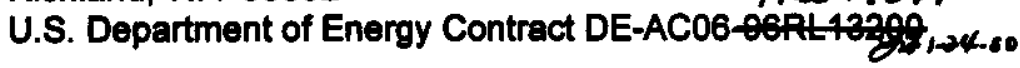 \\ EDT/ECN: $625^{8} 86$ \\ UC: 2000 \\ Org Code: 74700 \\ Charge Code: 102206 \\ B\&R Code: EW3130000 \\ Total Pages: 20 \\ Key Words: Design Review, Foot Clamp
}

Abstract: This report documents the Design Review performed for the foot clamp modification. The report documents the acceptability of the design, identifies the documents that were reviewed, the scope of the review and the members of the review team.

TRADEMARK DISCLAIMER. Reforence herein to any specillc commercial product, procese, or eervice by trade name, trademark, manufacturer, or othenwise, does not necesearlly constitute or imply its endorsement, recommendation, or favoring by the United States Government or any agency thereof or its contractors or subcontractors.

Printed in the Unked States of America. To obtain copies of this document, contact: Document Control Services, P.O. Box 950, Mallatop H6-08, Richland WA 99352, Phone (509) 372-2420; Fax (509) 376-4989.
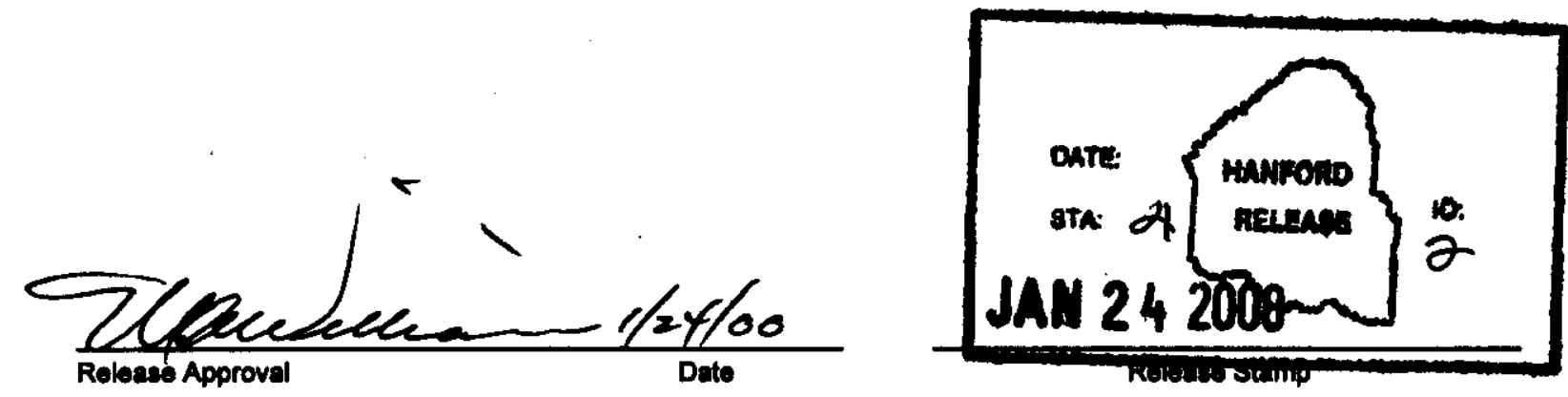


\section{RPP-5628 \\ Rev. 0 \\ FORMAL DESIGN REVIEW \\ FOOT CLAMP MODIFICATION}

Timothy C. Oten

January 18, 2000 


\section{RPP-5628 \\ FORMAL DESIGN REVIEW \\ FOOT CLAMP'MODIFICATION}

\subsection{SCOPE}

\subsection{Overview}

This report documents the formal design review of the foot clamp assembly for use with the Rotary Mode Core Sample (RMCS) trucks. The foot clamp assembly was originally designed for use with the Push Mode Sample (PMS) trucks, which are classified as General Service. The purpose of this design review was to determine whether the PMS foot clamp design is suitable for use on the RMCS trucks, which is a Safety Class application. The intent is to fabricate and test the RMCS and PMS foot clamp assemblies to satisfy Safety Class requirements so that they can be used in either application.

\subsection{Foot Clamp Design}

The foot clamp is designed to hold the drill string and prevent it from falling into the tank when the shielded receiver, quill rod or drill string hoist is disconnected, or in the event of a mechanical failure. The foot clamp assembly is made up of two pneumatically actuated pistons, a toggle style isolation valve and a three way isolation valve, a pressure gauge, a structural frame and miscellaneous tubing, nuts, bolts and fittings. The pistons are spring actuated to close and require air pressure to open; they fail closed on loss of air. The pistons are located opposite each other in the frame and extend toward each other to effectively clamp the drill string between them. Serrated jaws are attached at the end of each piston to ensure that the drill string does not slip when force is applied through the piston. The two valves are installed in series in the air supply line to the actuator to ensure that the foot clamp is not inadvertently opened. The foot clamp is designed for use with $2 \frac{1}{2}$ " fluted or $2 \frac{1}{4}$ " non-fluted drill string.

\subsection{Documents Reviewed}

The following documents were reviewed:

- ECN 655611, dated 10/22/99. Modifications to PMS Foot Clamp Assembly.

- Site Fabrication Services Work Package. Testing results for foot clamp units 1, 2 and 3, Work Order 2H9903622/F.

- Foot Clamp Compliance Matrix.

- H-2-690138, Sheet 1 of 6, Rev. 0, Footclamp Assembly.

- H-2-690138, Sheet 2 of 6, Rev. 0, Footclamp Assembly.

- H-2-690138, Sheet 3 of 6, Rev. 0, Footclamp Details.

- H-2-690138, Sheet 4 of 6, Rev. 0, Footclamp Details.

- H-2-690138, Sheet 5 of 6, Rev. 0, Footclamp Details.

- H-2-690138, Sheet 6 of 6, Rev. 0, Footclamp Details. 


\subsection{SUMMARY}

The formal design review identified a number of comments to be incorporated into the design of the foot clamp. Based on a review of the final ECN (ECN 655621), there are no outstanding action items. The design review is complete and the foot clamp design is acceptable for the RMCS safety class application.

\subsection{DOCUMENTATION}

\subsection{Design Review Checklist}

A design review checklist was prepared to document the overall assessment of the foot clamp design. The checklist addresses major design considerations rather than individual requirements. The checklist is attached as Appendix A of this report.

\subsection{Design Review Committee}

The design review committee was selected to provide an independent assessment and review of the foot clamp design. Members were selected by the chairman with the concurrence of their respective managers. Members are listed below:

- Chairman: Timothy C. Oten

- Design Authority: George P. Janicek

- Cognizant Engineer: Troy R. Farris

- Quality Assurance: Michael L. McElroy

- Quality Assurance: John J. Verderber

- Safety: Cary D. Jackson

- Engineering: Henry F. Shumake, Jr.

- Engineering: Galen W. Wilson

\subsection{Meeting Minutes}

Meeting minutes from the design review were prepared and are included in Appendix B.

\subsection{Other Documents}

The compliance matrix and a portion of the Site Fabrication Services Work Package reviewed during the design review meeting are included in Appendix $\mathrm{C}$. 


\section{APPENDIX A \\ DESIGN REVIEW CHECKLIST}

(2 pages including cover page) 


\section{DESIGN REVIEW CHECKLIST \\ FOOT CLAMP MODIFICATION}

Documents/ECNs Reviewed: ECN 655611; Site Fabrication Work Package for Testing of Foot Clamp; Foot Clamp Compliance Matrix; ECN 655621

\section{Affected Document(s) (Optional)}

Yes No NA

[X] [ ] [ ] Were the design inputs correctly selected?

[X] [ ] [ ] Are assumptions necessary to perform the design activity adequately described and reasonable?

[ ] [ ] [X] Where necessary, are the assumptions identified for subsequent reverifications when the detailed design activities are completed?

[X] [ ] [ ] Was an appropriate design method used?

[X] [ ] [ ] Were the design inputs correctly incorporated into the design? Is the design output reasonable compared to design inputs?

[X] [ ] [ ] Are the necessary design input and verification requirements for interfacing organizations specified in the design documents or in supporting procedures or instructions? (Yes-testing of the foot clamp prior to use)

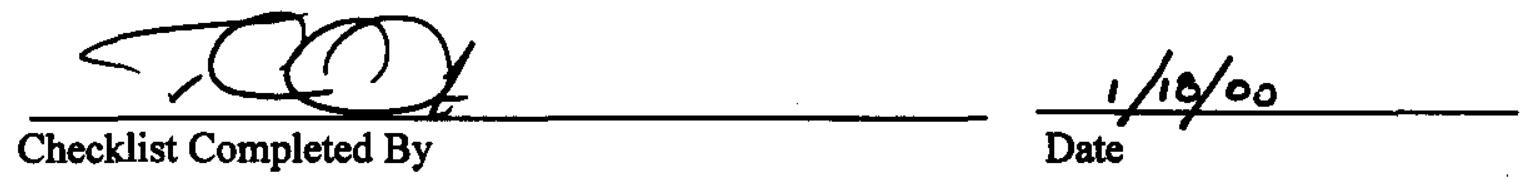


RPP-5628

Revision 0

APPENDIX B

\section{MEETING MINUTES}

(3 pages including cover page)

B-1 


\title{
FORMAL DESIGN REVIEW - SAFETY CLASS FOOT CLAMP (ECN 655611)
}

\author{
MEETING MINUTES (Rev. 1)
}

Prepared by T.C. Oten

2704 HV/Conference Room C207

November 5, 1999

\section{Design Review Team Members}

\author{
T. R. Farris, Cognizant Engineer \\ C. D. Jackson, Safety \\ G. P. Janicek, Design Authority \\ M. L. McElroy, Quality Assurance \\ T. C. Oten, Design Review Chairman \\ H. F. Shumake, Engineering \\ J. J. Verderber, Quality Assurance \\ G. W. Wilson, Engineering
}

\section{Design Review}

ECN 655611 was prepared and released to make modifications to the drawings for the foot clamp assembly used with trucks 1 and 2 . The foot clamp is classified as General Service for this application. The purpose of this design review was to determine whether the same foot clamp design is suitable for use on the Rotary Mode Core Sample trucks, which is a Safety Class application per HNF-SD-WM-SEL-044, Rev. 2. The intent is to fabricate and test all foot clamp assemblies to satisfy the requirements for the safety class application.

The foot clamp is designed for use with $2{ }^{1} /{ }^{\prime \prime}$ fluted or $2 \frac{1}{4}$ " non-fluted drill string. The assembly weighs approximately $140 \mathrm{lbs}$ as compared to the previous foot clamp design, which weighed approximately $90 \mathrm{lbs}$. In normal operation the foot clamp will have to be able to hold a maximum of approximately $250 \mathrm{lbs}$ of drill string. Documented test results show that the foot clamp can hold $1000 \mathrm{lbs}$; undocumented test results show that the drill string does not start to slip through the foot clamp until approximately $2000 \mathrm{lbs}$ is applied. The surface of the foot clamp that is in contact with the drill string is serrated to ensure that it grips the drill string tightly, even if the drill string is wet. The foot clamp is designed to fail closed on a loss of air. The combination of a toggle valve and a ball valve 
in series is intended to prevent inadvertently opening a single valve and releasing the drill string.

ECN 655611 will be revised to incorporate comments made by the design review team. The following are the comments on the $\mathrm{ECN}$ :

1. Add a note to Block 13a to state that the foot clamp must pass the test identified on H-2-690138, Sheet 1, Note 8 regarding close rate. The note will be revised to include testing of the toggle valve and verification that it does not leak. Testing must be completed without the needle valve installed to confirm the foot clamp meets the closure time requirements.

2. The SEL block should be checked in Block 19. Revised sections of the SEL should be included in the ECN.

3. Add the following documents to Block 20:

- VI 22601

- TO-080-518

- TO-080-519

- HNF-SD-WM-SEL-044

4. Revise Drawing H-2-690138, Sht. 3 to add a detail for a plate to cover the opening into the tank when the drill string is not in the riser.

5. Revise page 11, Detail 15 to show hidden lines and line up views (drafting error).

6. Verify that the Parts List on page 4 is consistent with the drawing revisions.

7. Revise the compliance matrix and add the affected sheets to the ECN. Incorporate the following comments (based on the preliminary matrix):

- In the "F\&R MET" column, describe how the requirement has been met.

- Revise the second item to read: "Upon mechanical failure, FC restrains the drill string, preventing a drop."

- In the fourth row, clarify that the foot clamp must be able to carry the load of the drill string and open wide enough to allow the drill string to pass through to be compatible.

- The item that states that the foot clamp jaws must incorporate a wedge design is not a requirement.

- Revise the seventh item to state that the foot clamp will be an enclosed assembly and have no inadvertent pinch points.

The review team members agreed that the changes could be closed by review of the modified ECNs by the chairman, with the chairman's signature on the ECN as record of acceptable closure. The meeting was adjourned. 
Revision 0

\section{APPENDIX C}

\section{OTHER DOCUMENTS}

(11 pages including cover page) 


\section{FOOT CLAMP (FC) H-2-690134-38}

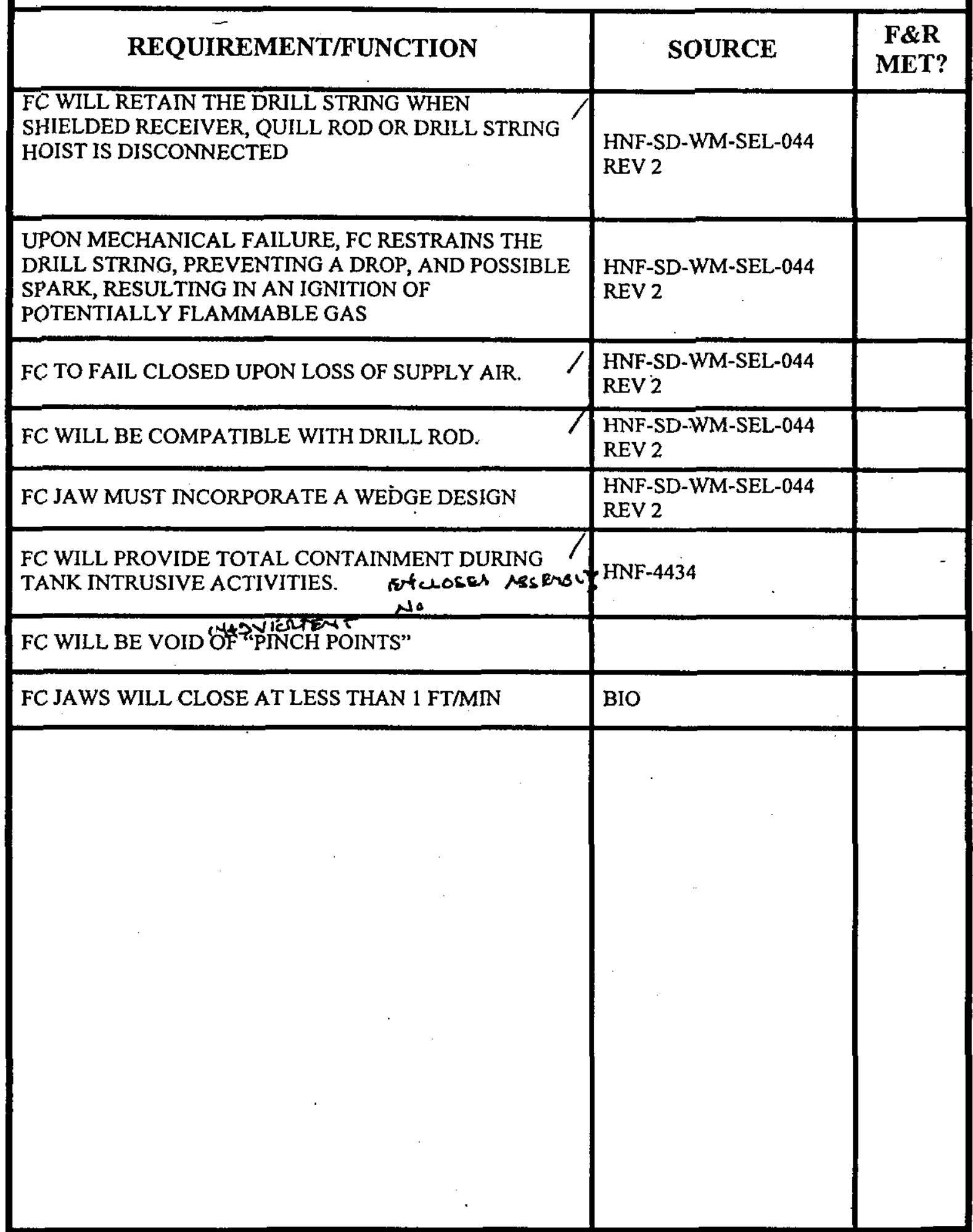

102250

Mech $Q A$ $D A$ sanicek 


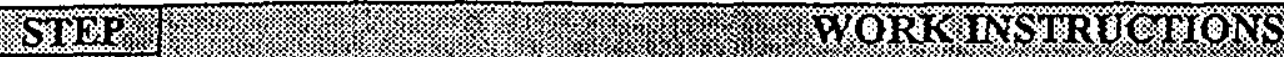 \\ CRA.FT \\ 130 \\ FUNCTIONAL TESTING PER DWG. H-2-690138 GENERAL NOTE \#8. TESTS 1 thru 3. \\ THESE TESTS ARE FOR UNIT \#1. \\ NOTIFY HENRY SHUMAKE 376-3404 AND ERIC WALDO 373-9207 FOR THEIR \\ SPECIAL INSTRUCTIONS AND INPUT IN THE FOLLOWING TEST. THE DRILL STRING WUL BE SUPPLIED BY CUSTOMER. "GO GAGE" IS LOCATED IN THE MACHINE SHOP TOOL CRIB. \\ NOTE: FOR THE PURPOSE OF THIS DOCUMENT, SLIPPAGE IS DEFINED AS THE MOVEMENT OF THE DRILL STRING RELATIVE TO THE FOOTCLAMP JAWS >0.25 INCH. \\ TESTING TO BE PERFORMED WITH 100 PSIG SUPPLY PRESSURE. \\ FUNCTIONAL TESTS: \\ 1. VERIFY THAT SUPPORT OF A MINIMUM VERTICAL LOAD OF 1000 POUNDS FORCE APPLIED TO 2 1/4", NON-FLUTED DRILL STRING HELD BY FOOTCLAMP WITHOUT SLIPPAGE.}

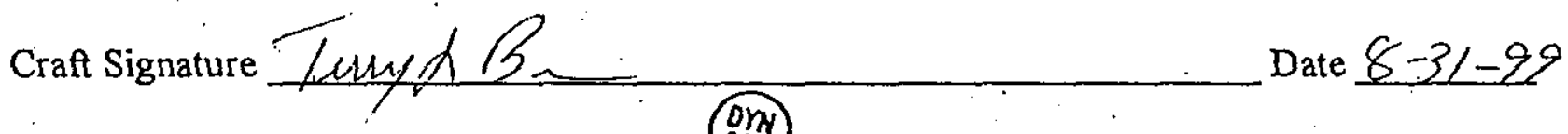
QC Signature

(ond Date $8-3194$

2. VERIFY THAT FOOTCLAMP DOES NOT OPEN UPON LOSS OF SUPPLY AIR. AIR IS TO BE REMOVED FOR THIS TEST.

Craft Signature

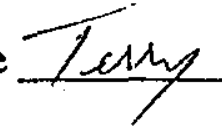

QC Signature
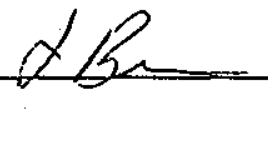

(DYN

Date $8-31-99$

Date $9: 31-87$

3. VERTFY THATT THE $\emptyset 1.895 \times 12$ " "GO GAGE" PASSES THROUGH THE NON-FLUTED DRILL STRING PRIOR TO AND WHILE BEING CLAMPED IN THE FOOTCLAMP.
Craft Signature
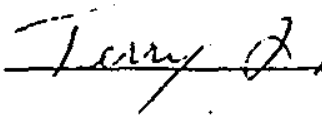
QC Signature

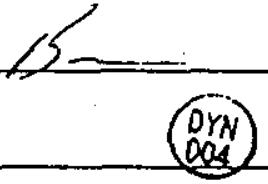
Date $8-31-98$
$\left(\begin{array}{l}D Y N \\ 0 \times 4\end{array}\right)$ Date $8 \cdot 31-99$ 
140 FUNCTIONAL TESTING PER DWG. H-2-690138 GENERAL NOTE \#8. TESTS 4 thru 6. THESE TESTS ARE FOR UNIT \#1.

NOTIFY HENRY SHUMAKE 376-3404 AND ERIC WALDO 373-9207 FOR THEIR SPECIAL INSTRUCTIONS AND INPUT IN THE FOLLOWING TEST. THE DRILL STRING WILL BE SUPPLIED BY CUSTOMER.

NOTE: FOR THE PURPOSE OF THIS DOCUMENT, SLIPPAGE IS DEFINED AS THE MOVEMENT OF THE DRILL STRING RELATIVE TO THE FOOTCLAMP JAWS >0.25 INCH.

TESTING TO BE PERFORMED WITH 100 PSIG SUPPLY PRESSURE.

FUNCTIONAL TESTS:

4. VERIFY THAT SUPPORT OF A MINIMUM VERTICAL LOAD OF 1000 POUNDS FORCE APPLIED TO $21 \frac{1}{2}$, FLUTED DRILL STRING HELD BY FOOTCLAMP WITHOUT SLIPPAGE.

Craft Signature QC Signature
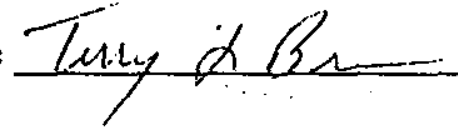

DYY Date $8-3,-97$ Date $8-3 /-55$

5. VERIFY THAT FOOTCLAMP DOES NOT OPEN UPON LOSS OF SUPPLY AIR. AIR IS TO BE REMOVED FOR THIS TEST.

Craft Signature Timig distis Date $8-31-99$

6. VERIFY THAT THE $\varnothing 1.895 \times 12 "$ "GO GAGE" PASSES THROUGH THE FLUTED DRILL STRING PRIOR TO AND WHILE BEING CLAMPED IN THE FOOTCLAMP.
Craft Signature

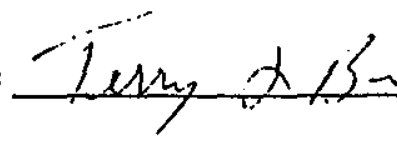
QC Signature
(OFM)
Date $8-3 /-29$
Date $\varepsilon \cdot 31-5 q$ 
FUNCTIONAL TESTING PER DWG. H-2-690138 GENERAL NOTE \#8. TESTS 7 \& 8. THESE TESTS ARE FOR UNIT \#1.

NOTIFY HENRY SHUMAKE 376-3404 AND ERIC WALDO 373-9207 FOR THEDR SPECIAL INSTRUCTIONS AND INPUT IN THE FOLLOWING TEST. THE DRUL STRING WWL BE SUPPLIED BY CUSTOMER.

NOTE: TESTING TO BE PERFORMED WITH 100 PSIG SUPPLY PRESSURE. FUNCTIONAL TESTS:

7. VERIFY THAT THE DISTANCE BETWEEN THE CLOSED JAWS IS LESS THAN 2 1/4".

Craft Signature

$\times$ QC Signature

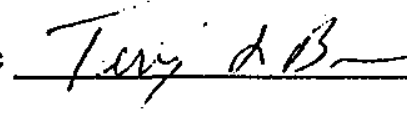

$\left(\begin{array}{l}0 Y M \\ 004\end{array}\right)$
Date $8-31-9$, Date $8 \cdot 31-5$

8. VERIFY BY USING A STOPWATCH AND RECORDING THE TIME PASSED FOR THE CLOSING OF THE JAWS ON THE FOOTCLAMP. JAW CLOSURE RATE NOT TO EXCEED ONE FOOT PER SECOND. CLOSURE RATE IS . 84 SECOND(S) FOR $31 / 4 !$ INCHES.

Craft Signature QC Signature Date $8-31-99$

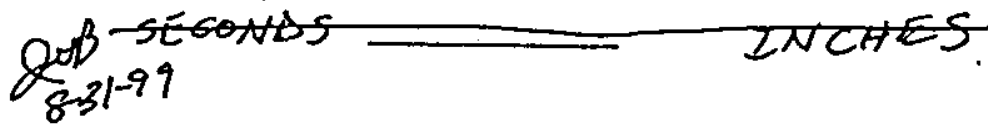




\section{STL?

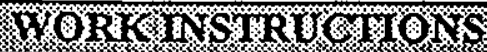 \\ GRAHT \\ 160 FUNCTIONAL TESTING PER DWG. H-2-690138 GENERAL NOTE \#8. TESTS 1 thru 3. THESE TESTS ARE FOR UNIT \#2. \\ NOTIFY HENRY SHUMAKE 376-3404 AND ERIC WALDO 373-9207 FOR THEIR SPECIAL INSTRUCTIONS AND INPUT IN THE FOLLOWING TEST. THE DRUL STRING WILL BE SUPPLIED BY CUSTOMER. "GO GAGE" IS LOCATED IN THE MACHINE SHOP TOOL CRIB.}

NOTE: FOR THE PURPOSE OF THIS DOCUMENT, SLIPPAGE IS DEFINED AS THE MOVEMENT OF THE DRILL STRING RELATIVE TO THE FOOTCLAMP JAWS >0.25 INCH.

TESTING TO BE PERFORMED WITH 100 PSIG SUPPLY PRESSURE.

FUNCTIONAL TESTS:

1. VERIFY THAT SUPPORT OF A MINIMUM VERTICAL LOAD OF 1000 POUNDS FORCE APPLIED TO 2 1/", NON-FLUTED DRILL STRING HELD BY FOOTCLAMP WITHOUT SLIPPAGE.

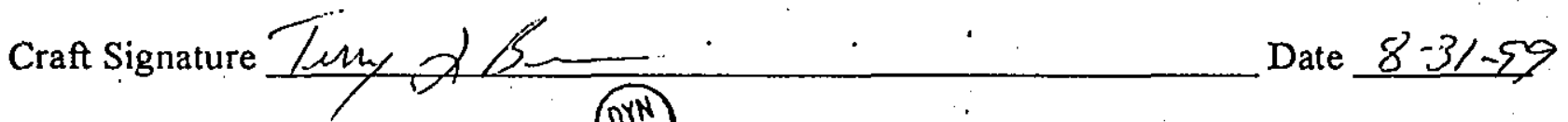
f QC Signature

(0) Date $83 /-95$

2. VERIFY THAT FOOTCLAMP.DOES NOT OPEN UPON LOSS OF SUPPLY AIR. AIR IS TO BE REMOVED FOR THIS TEST.

raft Signature

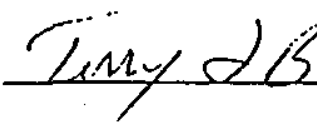

f QC Signature Date $8-31-99$ Date $831-55$

3. VERIFY THAT THE $\varnothing 1.895 \times 12 "$ "GO GAGE" PASSES THROUGH THE NON-FLUTED DRILL STRING PRIOR TO AND WHILE BEING CLAMPED IN THE FOOTCLAMP.

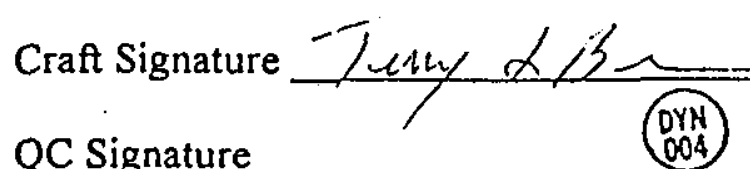
Date $8-3 /-95$ QC Signature Date $s-3(-8)$ 


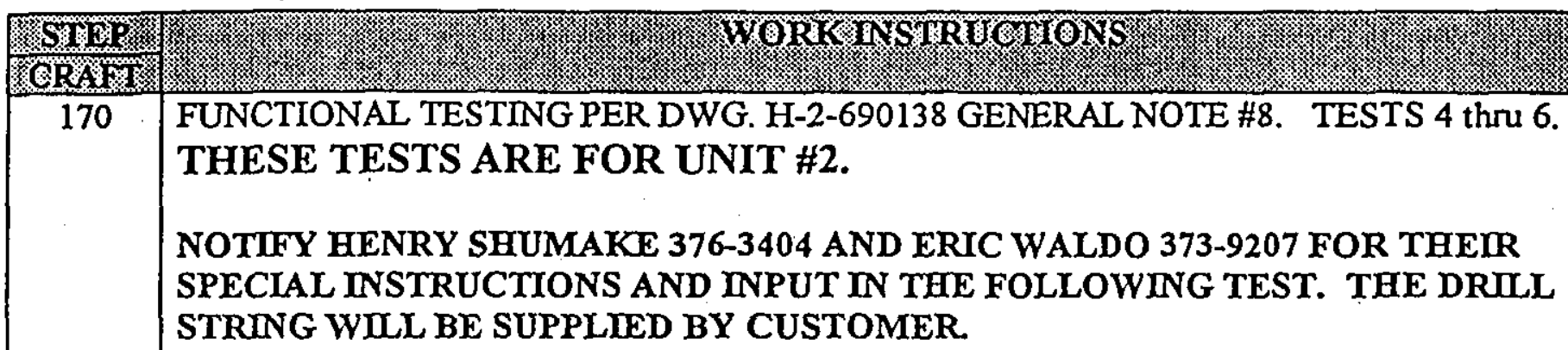

NOTE: FOR THE PURPOSE OF THIS DOCUMENT, SLIPPAGE IS DEFINED AS THE MOVEMENT OF THE DRILL STRING RELATIVE TO THE FOOTCLAMP JAWS >0.25 INCH.

TESTING TO BE PERFORMED WITH 100 PSIG SUPPLY PRESSURE.

FUNCTIONAL TESTS:

4. VERIFY THAT SUPPORT OF A MINIMUM VERTICAL LOAD OF 1000 POUNDS FORCE APPLIED TO $21 / 2 "$, FLUTED DRILL STRING HELD BY FOOTCLAMP WITHOUT SLIPPAGE.

Craft Signature T(1.2y $x / 5$. Date $8-31-97$

QC Signature

(OYM) Date $8 \cdot 31-59$

5. VERIFY THAT FOOTCLAMP DOES NOT OPEN UPON LOSS OF SUPPLY AIR. AIR IS TO BE REMOVED FOR THIS TEST.

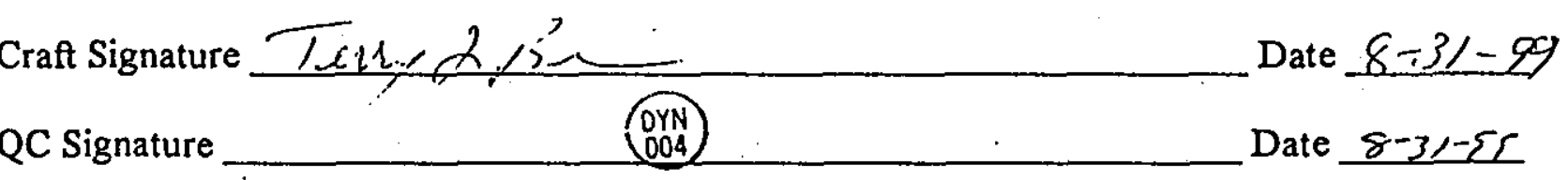

6. VERIFY THAT THE $\emptyset 1.895 \times 12$ " "GO GAGE" PASSES THROUGH THE FLUTED DRULL STRING PRIOR TO AND WHILE BEING CLAMPED IN THE FOOTCLAMP.

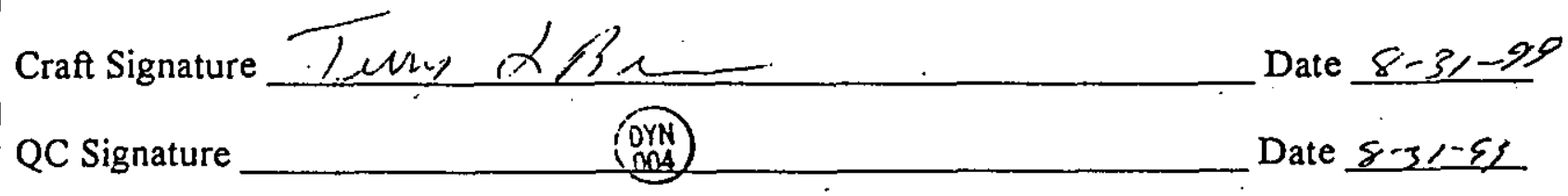




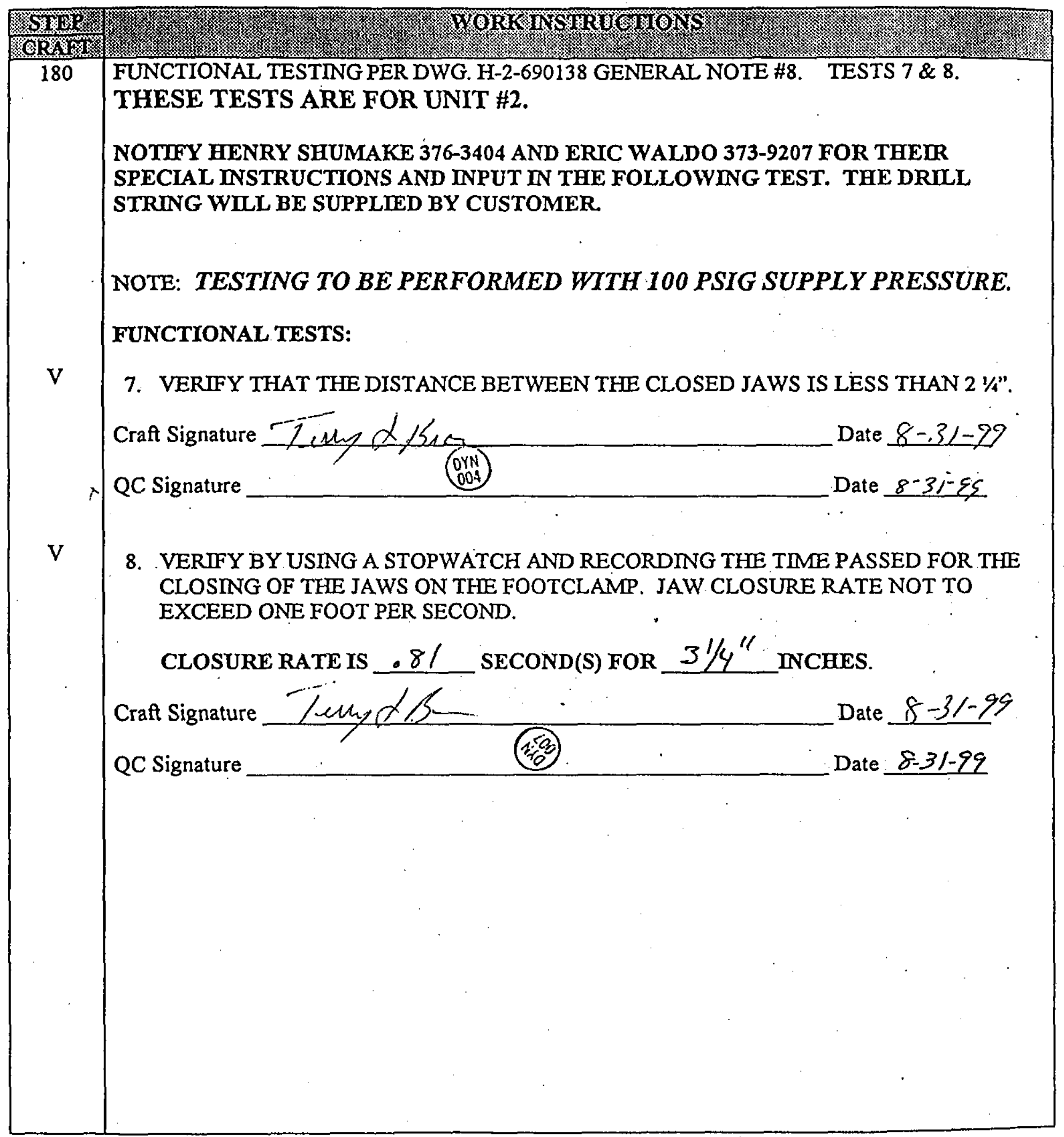


190 FUNCTIONAL TESTING PER DWG. H-2-690138 GENERAL NOTE \#8. TESTS 1 thru 3. THESE TESTS ARE FOR UNIT \#3.

NOTIFY HENRY SHUMAKE 376-3404 AND ERIC WALDO 373-9207 FOR THERR SPECIAL INSTRUCTIONS AND INPUT IN THE FOLLOWING TEST. THE DRILL STRING WUL BE SUPPLIED BY CUSTOMER. “GO GAGE” IS LOCATED IN THE MACHINE SHOP TOOL CRIB.

NOTE: FOR THE PURPOSE OF THIS DOCUMENT, SLIPPAGE IS DEFINED AS THE MOVEMENT OF THE DRILL STRING RELATIVE TO THE FOOTCLAMP JAWS >0.25 INCH.

\section{TESTING TO BE PERFORMED WITH 100 PSIG SUPPLY PRESSURE.}

FUNCTIONAL TESTS:

1. VERIFY THAT SUPPORT OF A MINIMUM VERTICAL LOAD OF 1000 POUNDS FORCE APPLIED TO $21 / 4$ ", NON-FLUTED DRILL STRING HELD BY FOOTCLAMP WITHOUT SLIPPAGE.
Craft Signature

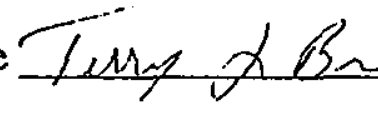
$\left(\begin{array}{l}\text { DYM } \\ 004\end{array}\right.$ Date $8-31-98$
QC Signature Date $8 \cdot 3$ - -5

2. VERIFY THAT FOOTCLAMP DOES NOT OPEN UPON LOSS OF SUPPLY AIR. AIR IS TO BE REMOVED FOR THIS TEST.

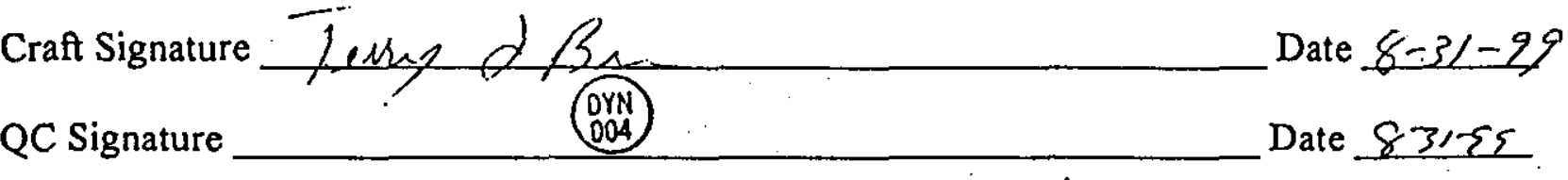

3. VERIFY THAT THE $\emptyset 1.895 \times 12$ " "GO GAGE" PASSES THROUGH THE NON-FLUTED DRULL STRING PRIOR TO AND WHILE BEING CLAMPED IN THE FOOTCLAMP.

Craft Signature
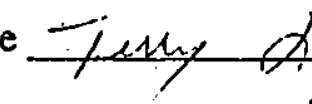

QC Signature

(oYN Date $\underline{\varepsilon-3}-29$ Date $s<31-49$ 


\section{STEY}

GRAT H

200

\section{WORK MSTRTUCMTONS}

FUNCTIONAL TESTING PER DWG. H-2-690138 GENERAL NOTE \#8. TESTS 4 thru 6. THESE TESTS ARE FOR UNIT \#3.

NOTIFY BENRY SHUMAKE 376-3404 AND ERIC WALDO 373-9207 FOR THEIR SPECIAL INSTRUCTIONS AND INPUT IN THE FOLLOWING TEST. THE DRILL STRING WIL BE SUPPLIED BY CUSTOMER.

NOTE: FOR THE PURPOSE OF THIS DOCUMENT, SLIPPAGE IS DEFINED AS THE MOVEMENT OF THE DRILL STRING RELATIVE TO THE FOOTCLAMP JAWS >0.25 INCH.

\section{TESTING TO BE PERFORMED WITH 100 PSIG SUPPLY PRESSURE.}

FUNCTIONAL TESTS:

4. VERIFY THAT SUPPORT OF A MINIMUM VERTICAL LOAD OF 1000 POUNDS FORCE APPLIED TO 2 1/2", FLUTED DRILL STRING HELD BY FOOTCLAMP WITHOUT SLIPPAGE.

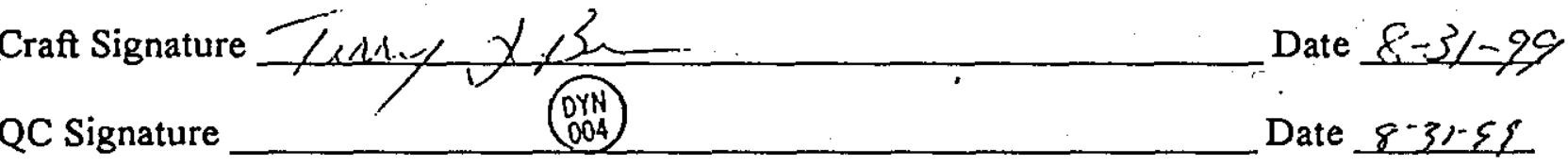

5. VERIFY THAT FOOTCLAMP DOES NOT OPEN UPON LOSS OF SUPPLY AIR. AIR IS TO BE REMOVED FOR THIS TEST.

Craft Signature

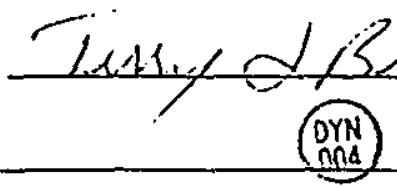
Date $8-3 /-98$ QC Signature OYN Date $8-31-59$

6. VERIFY THAT THE $\emptyset 1.895 \times 12$ " "GO GAGE" PASSES THROUGH THE FLUTED DRUL STRING PRIOR TO AND WHILE BEING CLAMPED IN THE FOOTCLAMP.
Craft Signature

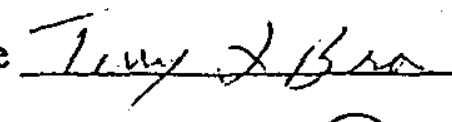 Date $85-3 /-99$

1. QC Signature Date $8-31-95$ 


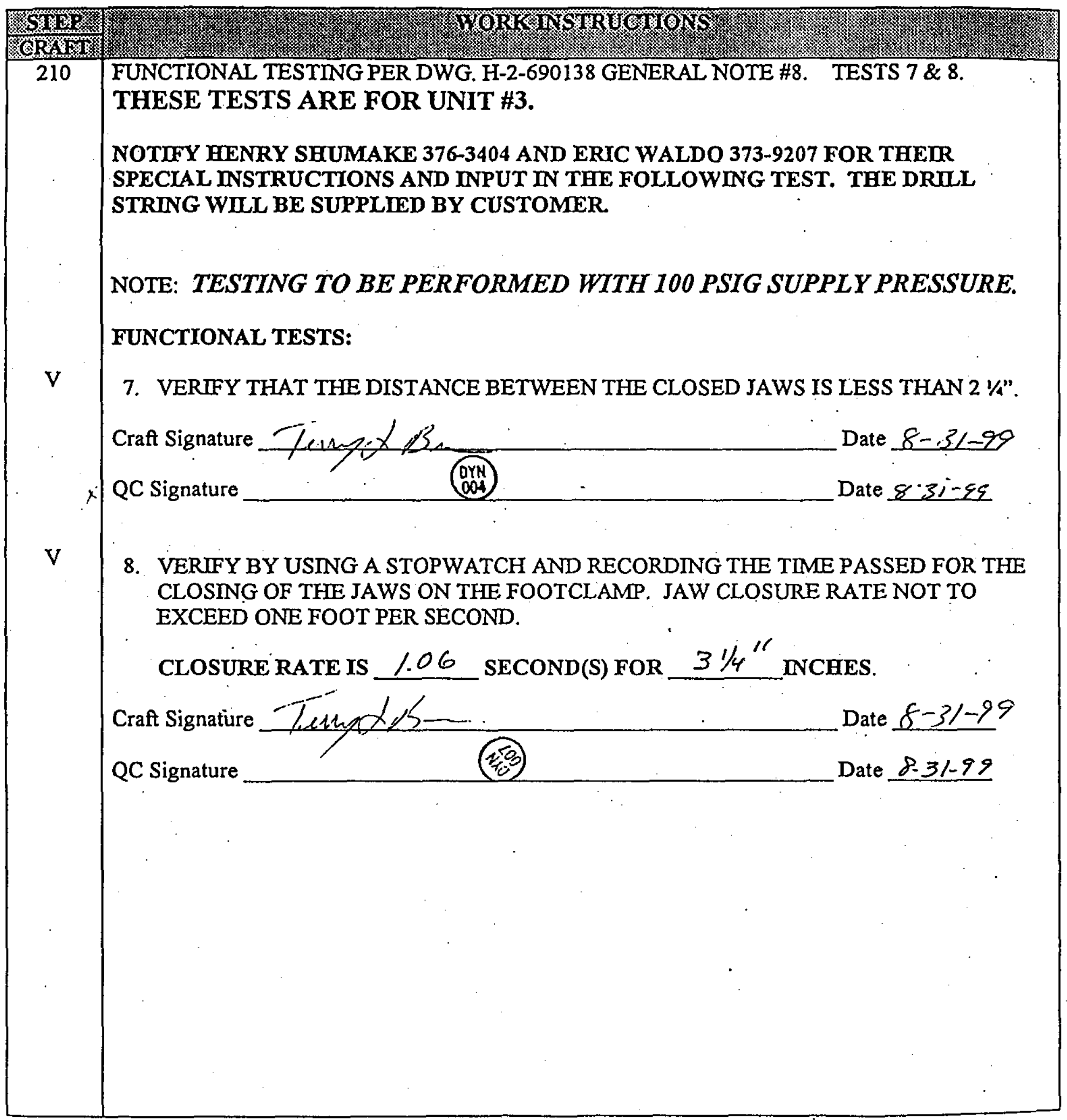




\section{DISTRIBUTION SHEET}

To

Distribution

Project TitieN Work Order

Formal Design Review- Foot Clamp Modification
Page 1 of 1

Date $01 / 20 / 00$

EDT No. 628086

ECN No. N/A

\section{Name}

T. R. Farris

C. D. Jackson

G. P. Janicek

M. L. McElroy

T. C. Oten

H. F. Shumake

J. S. Scholfield

\section{Central Files}

DPC

DOE Reading Room

PNNL Tech Library
From

Equipment Engineering

\begin{tabular}{|c|c|c|c|c|}
\hline MSIN & $\begin{array}{c}\text { Text } \\
\text { With All } \\
\text { Attach. }\end{array}$ & Text Only & $\begin{array}{c}\text { Attach./ } \\
\text { Appendix } \\
\text { Only }\end{array}$ & $\begin{array}{c}\text { EDT/ECN } \\
\text { Only }\end{array}$ \\
\hline$S 7-12$ & $x$ & & & \\
\hline $57-34$ & $x$ & & & \\
\hline$S 7-12$ & $x$ & & & \\
\hline $57-07$ & $x$ & & & \\
\hline R $1-56$ & $x$ & & & \\
\hline S7-12 & $x$ & & & \\
\hline $57-12$ & $x$ & & & \\
\hline B1-07 & $x$ & & & \\
\hline H6-08 & $x$ & & & \\
\hline $\mathrm{H} 2-53$ & $x$ & & & \\
\hline$P 8-55$ & $x$ & & & \\
\hline
\end{tabular}

